\title{
Organic Cocoa Value Chain Sustainability: The Perception of São Tomé and Príncipe's Stakeholders
}

\author{
Ibrahim Prazeres ${ }^{1}$, Maria Raquel Lucas ${ }^{1}$ (D) and Ana Marta-Costa ${ }^{2, *(D)}$ \\ 1 CEFAGE-Centre for Advanced Studies in Management and Economics, University of Évora, \\ 7000-809 Evora, Portugal; gibaedy@gmail.com (I.P.); mrlucas@uevora.pt (M.R.L.) \\ 2 CETRAD—Centre for Transdisciplinary Development Studies, University of Trás-os-Montes e Alto \\ Douro (UTAD), 5001-801 Vila Real, Portugal \\ * Correspondence: amarta@utad.pt
}

check for updates

Citation: Prazeres, I.; Lucas, M.R.; Marta-Costa, A. Organic Cocoa Value Chain Sustainability: The Perception of São Tomé and Príncipe's Stakeholders. Sustainability 2022, 14, 136. https://doi.org/10.3390/ su14010136

Academic Editor: Markus Keck

Received: 12 November 2021

Accepted: 21 December 2021

Published: 23 December 2021

Publisher's Note: MDPI stays neutral with regard to jurisdictional claims in published maps and institutional affiliations.

Copyright: (c) 2021 by the authors Licensee MDPI, Basel, Switzerland. This article is an open access article distributed under the terms and conditions of the Creative Commons Attribution (CC BY) license (https:// creativecommons.org/licenses/by/ $4.0 /)$.

\begin{abstract}
Cocoa farming in São Tomé and Príncipe (STP) faces several challenges due to its poor socioeconomic context, the adverse impact of climate changes, the complex and limited access to global value chains, and worldwide demand pressure for higher cocoa quality and productivity. This exploratory research investigates potential pathways to a more sustainable organic cocoa (OC) production in STP by mapping the perceptions of the stakeholders involved in its value chain. Qualitative interviews, field observation, and focus group discussions were applied to understand how sustainability dimensions, drivers, impacts, and challenges of OC are perceived and how these three dimensions can be improved and balanced. The gathered perceptions are rather diverse, reflecting the stakeholders' position and knowledge of the specific contexts and processes. Producers do not perceive how governance is adopting new organizational structures or practices that allow for an effective sustainability improvement. Most stakeholders recognize that market-related factors drive the sustainability adoption and that financing-related constraints challenge their wide implementation. There are trade-offs and power asymmetries in the OC value chain, which manifest differently, due to the governance approaches, processes, overall regulations, and training of producers. An alignment of perceptions and activities as well as a stronger cooperation between cooperatives, private firms, and public institutions is strongly recommended.
\end{abstract}

Keywords: cocoa value chain; drivers; impacts and challenges; governance; organic production; qualitative analysis; sustainability concept

\section{Introduction}

Agriculture, agribusiness, and food markets are becoming prime sustainable development areas in many countries. Moreover, the cocoa value chain sustainability is increasing as a global concern due to the fact that a large part of the used land is obtained through deforestation, which has a huge impact on local biodiversity and social cohesion [1]. These are foremost threats to the environment, which have already taken place on a major scale in cocoa-producing countries [2]. Additionally, the overage tree stocks, the repercussions of disease and pest infestation, the political instability in West Africa, the lack of agricultural professionalism, the absence of infrastructure, the low income of farmers, the shortcomings of the educational and financial systems, and child labor exploitation in cocoa-growing regions are further concerns [3,4]. Thus, the sustainability dimensions represent a relevant issue for the management and decision making in the cocoa value chain.

Cocoa is one of the main goods in the world's agricultural trade markets, occupying the third position in exports [5,6]. Its production is primarily concentrated in the tropics (Africa), which represent two-thirds of the world production and where Côte d'Ivoire is the main producing country with around $40 \%$ of the world production [7]. In STP, this agricultural commodity plays an important role in the country's exports and is a vital 
contributor to smallholder producers' income, although it is facing climate challenges and several other risks [8]. In this country, the cocoa value chain is very fractional at the producer level, where approximately $70 \%$ of organic producers develop their activity in plots smaller than 2 hectares [9,10]. In 2018, the number of organic cocoa producers was approximately 3300 [9], and cocoa, which occupied about $80 \%$ of the agricultural area, represented $90 \%$ of the country's export earnings [11]. In addition to its contribution to gross domestic product, through heavy weight in exports in the agricultural sector, the cocoa culture guarantees the livelihood of many families as it creates jobs, develops local microeconomies, and provides a positive international image of the country [9]. Similar to other cocoa-producing countries, (1) the value chain is interestingly embedded in a complex global network, from the producer to the manufacturing of cocoa into chocolate and the final consumers [1] and their persistently growing demand; (2) the chain is still missing high-quality planting materials to improve the quality of cocoa and initiatives to increase productivity and farmer profit [12,13]; and (3) there are some uncoordinated interventions from public organizations, private entities, and exporters, such as farmer trainings, organic certification schemes, and dissemination of good agricultural practices, and the value chain remains unprofitable and unsustainable, especially for cocoa producers [13].

Given the socioeconomic and environmental relevance of organic cocoa in STP, the perceptions of smallholder farmers and other related stakeholders of their own sustainability are needed for three main reasons. First, farmers' conservationist behavior (and the concomitant ecological outcomes) is influenced by farmers' attitudes and perceptions of natural resources and the environment [14]. Second, farmers' perceptions of the attributes of conservation programs are correlated with program adoption [15-17], and third, compliance with agro-environmental programs (regulations) is connected to farmers' awareness of program rules and enforcement practices [18-20]. Furthermore, the actual state of the sustainability of the organic cocoa value chain also matters because it can have an impact on the agro-ecological system, the social and environmental context of producing communities, the economic viability of cocoa, and farmer well-being, as well as the viability of the consumer market, which directly relates to consumer trust in the organic production and consecutive willingness to pay a premium price for such.

This article aims to analyze and map out the perceptions of the key actors of value chains for cocoa, particularly farmers and other stakeholders involved in improving the sustainability of the production of organic cocoa in STP towards sustainability. It is an exploratory and qualitative research that tries to understand how sustainability is perceived and assessed in terms of its importance, impacts, and challenges. The following sections will describe the methodology used, the generated results, and the discussion with respect to former studies. Future research directions are highlighted in the last section.

\section{Materials and Methods}

\subsection{Research Approach and Theoretical Framework}

The methodology employs a combination of institutional and bibliographic analysis (Stage 1) with expert interviews, focus groups, and field observation (Stage 2). The first, supported in the work of Prazeres [9], allowed for the identification of the main stakeholders in STP's organic cocoa value chain and the connections between them and the institutional landscapes of certification among other regulations. The definition of institution was considered in a broad sense, as suggested by Hindriks and Guala [21] and Dompreh et al. [19]. It includes policies and organizations, such as cooperatives and certification bodies, that prescribe several actions to be taken to ensure the sustainable production, processing, and trade of commodity crops. It also includes other formal and informal institutions that can interact with many of the processes encompassed in sustainability standard during its design, adoption, and implementation [22]. 
In Stage 2, the main drivers, impacts, and challenges related to sustainability were identified through a qualitative analysis of interviews with farmers and their associations, cooperative representatives, certification bodies and experts, and a representative of the main stakeholders involved in organic cocoa production. The main rationale for eliciting the perceptions of multiple stakeholders is that they can hold different perspectives on key aspects and outcomes of sustainability processes in the organic cocoa value chain. These different perceptions might affect sustainability transition processes and their adoption, legitimacy, performance, sustainability levels, and standards. Understanding the perspectives of different stakeholders is a key element of transdisciplinarity in sustainability science [23], which has been widely used to study different development interventions [24,25].

\subsection{Data Collection and Analysis}

While the primary data were collected following an exploratory research approach, the secondary data resulted from an extensive literature review. In Stage 1, the value chain structure identified in the previous work of Prazeres [9] was upgraded through field observation and information provided by stakeholders and other pertinent readings of internal official documents associated with the organic cocoa value chain. The documents were collected from relevant organizations (Ministry of Agriculture and some of their directions and agencies, Centre for Agronomic and Technological Research (CIAT), cooperatives, and associations) and other stakeholders, such as distributors and exporters. This information was consolidated in a schematic diagram that summarizes the main relations between stakeholders.

In Stage 2, the exploratory primary data collection started with the selection of the organic cocoa stakeholders' interviewees. Then, the qualitative interviews were conducted during 3 months of research (January-March 2021). Aiming at capturing the breadth and totality of individual perspectives on the drivers, impacts, and barriers of sustainability, these interviews were executed with the use of a semistructured interview guide. This interview guide was organized into six topics related to the organization origin and the respondent role in the enterprise; the structure of the STP organic cocoa value chain and its relationship with the sustainability concept and dimensions; and barriers, drivers, impacts, and pathways to the future of this value chain. However, the interviews mostly included open-ended questions to allow respondents to elaborate freely on their answers, to probe new areas of interest mentioned by the interviewees, and to guarantee the exploratory character of the study. Most questions were identical for all respondents, allowing for some level of consistent perception elicitation between the participants.

The study used the international criteria of sustainability [26-28]: (1) economic sustainability (high economic productivity, high product quality, limited price volatility, strong investments platforms, and market diversification); (2) social sustainability (improved livelihoods of poor farming households, equal distribution of the added value, equal rights for women, and eradicated child labor); and (3) environmental sustainability (resilient and sustainable food production systems, use of good agricultural practices, maintenance of the ecosystem, and biodiversity conservation).

The individual respondents were directly involved in the organic cocoa value chain. The selection criteria of the individual interviewees were (a) centrality and individual and/or organization relevance to the organic cocoa value chain, (b) representation of a wide and legitimate set of individual perspectives, and (c) answer clarity and comprehensiveness. As the intention of the study was to elicit the totality of the different perceptions of the sustainability concept and the drivers, impacts, and barriers of sustainability, the number of interviewees solely ended when no original perspectives could be obtained. 
Overall, 25 respondents were interviewed. Six were female and 19 male, with the ages ranging from 30 to 59 years, and the average age was 43 . Sixty percent held an academic degree, and the others attended secondary school. In particular, they were interviewed individuals reflecting a wide variety of stakeholders who play a role in STP's organic cocoa value chain and work experience between 1 and 8 years, with an average of 3 years. They included governmental institutions $(n=4)$, private companies $(n=3)$, nongovernmental organizations (NGOs; $n=1)$, researchers $(n=2)$, certification bodies $(n=2)$, cooperatives $(n=4)$, distributors and exporters ( $\mathrm{DE}=4)$, and sociotechnicians $(n=5)$. This last group are cooperatives technicians, who provide training and technical support to producers and substitute state-owned extension services [8]. Being from different organizations and contexts, the selected individual stakeholders reflect different interests, roles, and knowledge of sustainability. To triangulate whether the selected individual stakeholders were the most appropriate, the respondents we asked during the interviews to indicate experts whom they perceived to be key players in the organic cocoa value chain in STP. This allowed the research to have a reality check concerning the most relevant individual stakeholders. All the interviews were conducted face-to-face and were audio-recorded after securing the consent of each respondent. Nonetheless, two interviews were complemented through telephone and WhatsApp.

Apart from the interviews, with the aim of capturing specifically the collective perspective of the cocoa farmers, the study conducted 10 focus groups until July of 2021 with 10 farmer participants from the two organic cocoa cooperatives. The anonymity of the participants was preserved, and prior to the group discussions, all the participants received a short concept note with background information detailing the motivation and aim of the study. They also received a consent form, which informed them of their rights and the ethical guidelines that the study adhered to [29]. The organic cocoa farmers' selection (maximum of 20 per group and per meeting) was based on purposive sampling whereby the representatives of the cooperatives, associations, and communities were sought out based on their level of knowledge of the participants. This took place in the districts of Lembá, Lobata, Me-Zochi, and Cantagalo, where community farmers have converted all conventional cocoa production into organic production and where, inside their associations and cooperatives, they are trying to achieve greater value and thus greater profitability to the producers.

They included 120 producers from the Cooperative for the Production and Export of Organic Cocoa (CECAB) and 80 from the Cooperative for the Production and Export of Cocoa (CECAC11), and only 66 were female. The participants' ages were between 26 and 71 years old, with an average age of 44 years old among CECAB members and 49 among CECAC11 members. Their marital status was mainly single, and work experience in the organic cocoa value chain was between 1 and 21 years, with an average of 12 years. Ninety percent attended primary school, and only $6 \%$ attended secondary school. Those from CECAC11 were trained in grafting and pruning, and those from CECAB in organic cocoa.

These focus groups were guided (structured into six topics, such as the interview guide), although they did not follow a strict order of questions, allowing the participants to have a free discussion. This method allowed for the collection of diverse producer perspectives concerning the sustainability concept and the drivers, impacts, and barriers of the sustainability of the organic cocoa value chain. Afterwards, the results generated from these 10 focus groups were compared with the results from the individual interviews. Lastly, field observation took place during the entire period of empirical data collection. 
Concerning the data analysis, the interviews and focus group information outputs were transcribed verbatim, and the transcripts were used to undertake content analysis using NVivo software. Concerning the issue of saturation of interview numbers [30], the whole material (field observation notes, interviews, and focus group information) was assessed to be sufficient for such pilot study. An inductive approach was followed to draw out the themes and categories from the data focused on general perceptions. The themes and keywords used for the content analysis were supplied by the reviewed literature on the sustainability drivers, barriers, and impact on the cocoa value chain. Table 1 sums up the methodology used in the research.

Table 1. Research methods.

\begin{tabular}{|c|c|c|}
\hline Methodology & Involved Stakeholders/Sources & Targeted Focus \\
\hline Extensive literature review & $\begin{array}{l}\text { Internet and bibliographic search and reviews of } \\
\text { project reports, peer-reviewed publications, and } \\
\text { unpublished academic theses/dissertations }\end{array}$ & $\begin{array}{l}\text { To gather secondary data that have been } \\
\text { used as baseline for the study }\end{array}$ \\
\hline Open qualitative interviews & $\begin{array}{l}\text { Governmental institutions (GI), cooperatives }(\mathrm{C}) \text {, } \\
\text { certification bodies }(\mathrm{CB}) \text {, private companies }(\mathrm{PC}) \text {, } \\
\text { nongovernmental organizations (NGO), research } \\
\text { center (RC), sociotechnicians (ST) }\end{array}$ & $\begin{array}{l}\text { To capture individual perspectives of the } \\
\text { sustainability concept and on the drivers, } \\
\text { impacts, and barriers of sustainability }\end{array}$ \\
\hline Focus group discussions & Organic cocoa producers (OCPs) & $\begin{array}{l}\text { To gather joint/collective perspectives of } \\
\text { organic cocoa farmers of the meaning of } \\
\text { the sustainability concept and of the } \\
\text { drivers, impacts, and barriers of } \\
\text { sustainability, and compare them with } \\
\text { the views of the individual actors who } \\
\text { were interviewed during the open } \\
\text { qualitative interviews }\end{array}$ \\
\hline Field observation & $\begin{array}{l}\text { Observing and listening within the local } \\
\text { producer context }\end{array}$ & $\begin{array}{l}\text { To triangulate all other methods with } \\
\text { additional information }\end{array}$ \\
\hline
\end{tabular}

A code of themes was developed based on interview and focus group contents to identify similarities, differences, and trends among the interviews. Themes were then organized and put into a visual diagram (Figure 1) that supports the organization, management, and interpretation of gathered data.

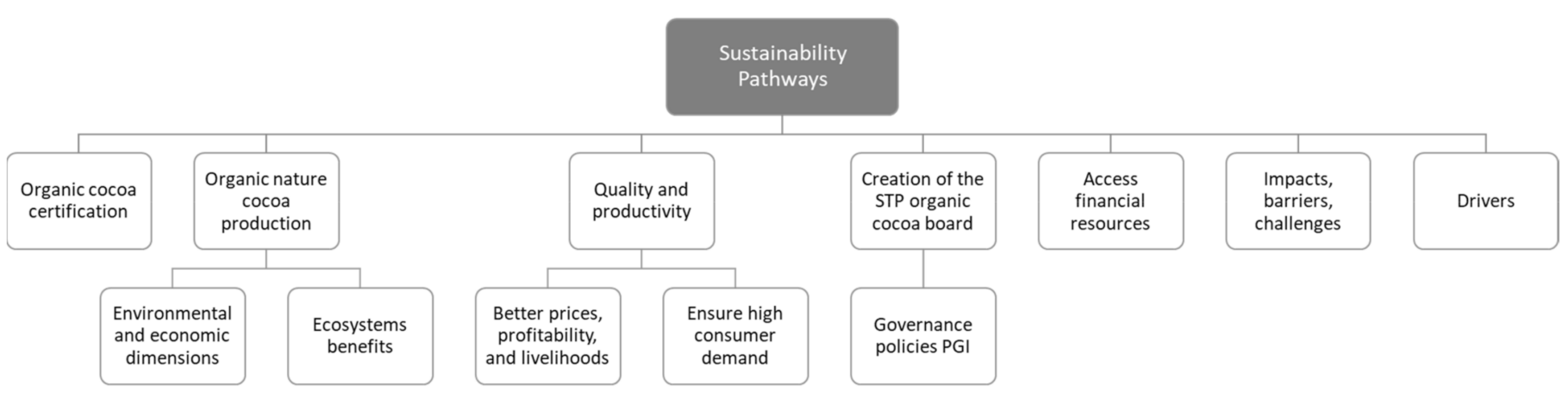

Figure 1. Themes coded in the interviews and focus groups regarding sustainability pathways.

\section{Results}

Table 2 synthetizes the key elements of sustainability perceptions gathered during the empirical work, which are detailed in the following subsections. 
Table 2. Key elements of sustainability perceptions gathered on the empirical work.

\begin{tabular}{|c|c|c|c|}
\hline Dimension & Concept and Current State & Drivers & Impacts and Barriers \\
\hline Economic & $\begin{array}{c}\text { Organic production } \\
\text { Consumer demand } \\
\text { Asymmetric value chain } \\
\text { Cocoa prices } \\
\text { Certification } \\
\text { Traceability } \\
\text { Quality standards }\end{array}$ & $\begin{array}{c}\text { Price stability } \\
\text { Premium price } \\
\text { Buyers' dependency } \\
\text { Market } \\
\text { Commercialization } \\
\text { Costs } \\
\text { Financial support }\end{array}$ & $\begin{array}{c}\text { Income sources } \\
\text { Financial and operational } \\
\text { Marketing } \\
\text { Costs } \\
\text { Innovation } \\
\text { Cocoa beans' quality } \\
\text { International demand }\end{array}$ \\
\hline Social & $\begin{array}{c}\text { Certification } \\
\text { Value chain governance } \\
\text { Profit } \\
\text { Livelihoods }\end{array}$ & $\begin{array}{c}\text { Governance } \\
\text { Training } \\
\text { Empowerment } \\
\text { Farming practices } \\
\text { Livelihoods } \\
\text { Extension services } \\
\text { Gender issues } \\
\text { Child labor } \\
\text { Equity }\end{array}$ & $\begin{array}{l}\text { Farmers' well-being } \\
\text { Health } \\
\text { Institutional capacity } \\
\text { Technical knowledge } \\
\text { Governmental policies } \\
\text { Governance } \\
\text { Bureaucracy }\end{array}$ \\
\hline Environmental & $\begin{array}{l}\text { Certification } \\
\text { Organic production } \\
\text { Organic features } \\
\text { Ecosystem services }\end{array}$ & $\begin{array}{c}\text { Soil fertility } \\
\text { Biodiversity } \\
\text { Cocoa plants' quality } \\
\text { Ecosystems' preservation }\end{array}$ & $\begin{array}{c}\text { Environmental pollution } \\
\text { Preservation of water sources } \\
\text { Deforestation } \\
\text { Biodiversity } \\
\text { Land tenure } \\
\text { Shade trees }\end{array}$ \\
\hline
\end{tabular}

\subsection{Institutional Landscape of the Organic Cocoa Value Chain}

Taking in to account the work of Prazeres [9] and the upgrade developed with information collected by field observation, interviews, and the focus group, this section shows the current organic cocoa value chain structure for STP. It comprises multiple stakeholders involving, among others, the producers, two cooperatives (CECAB and CECAC11), and the private sector (independent producers and companies (Satocão and Diogo Vaz), chocolate industry manufacturers and processors and traders, certification bodies, traders (distributors and exporters), and consumers) operating at the international, national, and local levels (Figure 2). Their involvements are not isolated, but they are connected in multiple ways. The government and civil society belong to the external environment of the organic cocoa value chain. Despite its large size, the international cocoa market is very concentrated, with few players representing a significant fraction of the market [9].

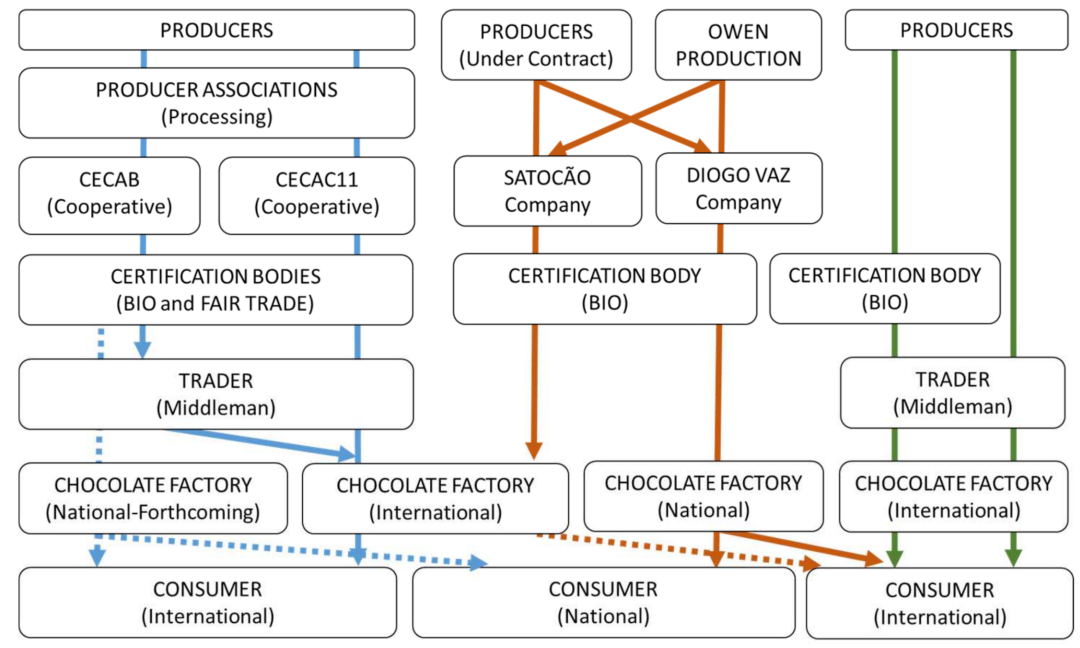

Figure 2. Organic cocoa value chain in STP. Source: Adapted from Prazeres et al. [8]. 
Each one of the cooperatives brings together several associations, organized by geographical area, which receive cocoa seed from their respective farmers [9]. According to Prazeres [9], farmers' training and motivation strategies, to guarantee production at the level and quality required by the market, are carried out by cooperatives, which provide training to member technicians. These later called "sociotechnicians" provide training and technical support to their producers, being paid for this task and replacing the role of state-owned extension services. One of the cooperatives (CECAB) is building a chocolate factory. Its manufacturing will begin shortly and will be destined for national and international markets. This new factory can be a solution to combine certification and a contract system. This way, the organic cocoa value chain can perform more effectively, shortening the marketing chain and increasing farmers' income value as suggested in the literature [31,32].

The configuration of connections within the organic cocoa value chain is under "pressure/demand" from international buyers (international/multinational companies and chocolate industry traders) and consumers concerned with sustainability, who change behaviors and attitudes, adopting more responsible consumption patterns. There is a rather stark difference between this context and the reason why the producers in STP end up adopting sustainable practices. The smallholders are integrated in two cooperatives, which produce practically all of the organic cocoa in STP. The organic cocoa certification is completed by independent private bodies, and the decision to adopt these schemes and standards rests on the cooperatives. These decisions are: (a) usually influenced by the stakeholders, such as the chocolate manufacturing industry traders and their respective representatives and other partners in the market, and (b) induced by market evolution signals, price expectations and growing sales, and market share. Independent organic cocoa smallholders, who are not integrated in the cooperatives and wish to get certificated, generally search and make direct contacts with the certification agencies and stablished networks and market connections to promote cocoa beans. All the decision-making processes rest with these producers.

The government agencies and institutions, which support the organic cocoa production in diverse ways, are associated with the Ministry of Agriculture. Through different funds and projects (International Fund for Agricultural Development (IFAD) and Smallholder Commercial Agriculture Project (PAPAC)), they financially support both cooperatives and their actions. The CIAT supports production though genetic improvement, selection of cocoa plants, and quality control of cocoa beans prior to exports. The civil society organizations and nongovernmental organizations that support the organic cocoa value chain and the cooperatives are: Action for Agricultural Development and Environmental Protection (ADAPPA), ADIL (Local Initiatives Development Action) Zatona, and National Federation of Small Farmers (FENAPA). They play a major role in implementing certification, through advocacy, farmer training, and sometimes research and information on funding access programs. Finally, other external important players in the organic cocoa value chain include (a) financial institutions (banks and others), (b) third-party certifying bodies that audit certified producers to confirm compliance with standards, and (c) independent research organizations, such as universities, particularly the University of Évora, which have developed a substantial amount of research in the cocoa value chain.

\subsection{Perceptions of the Concept and the Current State of Sustainability}

Mostly due to the use of open questions in the interviews, focus group discussions, and field observation, it can be exposed that STP's organic cocoa value chain has positive characteristics overall. All the individuals interviewed (public and nonpublic organizations, certification bodies, experts, cooperative representatives, sociotechnicians, and farmers) perceive the sustainability concept to be important for future generations. They see organic cocoa certification as a positive step towards improving the current sustainability state. Government representatives agree that the organic nature of cocoa 
production makes the value chain ecologically and economically sustainable. Moreover, some agro-ecological areas in STP, with specific soils and climatic conditions, produce high-quality organic cocoa with unique organoleptic features. Moreover, cooperative representatives $(C 1, C 2)$ highlight the ecosystems' benefits (ecosystem services) within the regions of cocoa production. However, when asking respondents about the overall current sustainability of the organic cocoa value chain, all agreed that an improvement is needed in all the dimensions.

"It is not in a bad situation but must be improved. I desire that it be improved."

(C2-Open qualitative interview)

The reasons presented for sustainability improvement are diverse. CB1, for instance, maintains that high consumer demand in organic cocoa sustainability standards is essential for the improvement of the current situation. Contrastingly, for NGO1, the reason laid on the social dimension of sustainability is generally or very often forgotten. For CB2, the problem is the type of organic cocoa value chain governance. ST1 and the PC2 agree that global cocoa prices are determinants of their current sustainability status.

"International cocoa prices are the problem. They determine the weak current state of organic cocoa sustainability in ST."

(ST1, PC2-Open qualitative interview)

When asking stakeholders through the open interviews which pathway suggested to be the most suitable for STP to achieve higher sustainability standards, the participants diverged in their choices. Likewise, the focus group revealed that the choices designated by the respondents varied significantly. No participant, during an individual interview or a focus group discussion, maintained the organic cocoa value chain in its current state. For farmers, CB1 and CB2, certification was the pathway that was further highlighted as a driver of sustainability. Their justification relied on the fact that certification is the easiest way to access a specific and profitable niche market, ensuring returns to farmers. In addition, it ensures the quality of organic cocoa beans and increases the traceability of the value chain. The high costs of certification and concerns regarding low premium prices paid by buyers were some of the greatest disadvantages perceived by the respondents, particularly by the cooperatives $(\mathrm{C} 1, \mathrm{C} 2)$. The private-driven pathway was chosen by $\mathrm{PC}$ (PC1, PC3), which was considered by government representatives to be having privileged access to financial resources. In addition, certification bodies (CB1, CB2) and ST (ST1, ST3, ST4, ST5) defend that an increase in production volumes and productivity could be directly linked to a joint effort between private entities and cooperatives. From the sociotechnician's perspective, this could lead to improvements on the economic and social dimensions of sustainability through greater profit and better livelihoods. However, the individualistic behavior of private actors and the existence of value chain asymmetric power were perceived to be great barriers, revealed due to the open-ended questions of the interviews and the focus groups.

Governmental institutions and cooperative representatives were undoubtedly in favor of a pathway driven by the public sector, more specifically through the cooperatives (GI1, GI3, GI4, C1, C2). All the participants of the stakeholders' group in the study maintained that price stabilization mechanisms are the driver that can increase the quality of organic cocoa and reduce the negative impact of volatility and international price fluctuations. Public funds to support cooperatives were perceived by the respondents belonging to the cooperatives and research centers to be insufficient to develop the value chain $(\mathrm{C} 1$, C2, RC1). The existence of corruption is weakening the sustainable improvement of the organic cocoa value chain, as revealed in the focus group interviews with the organic cocoa farmers. This matter was also maintained by the representatives of the private sector (PC1, PC3), the nongovernment organization (NGO1), the certification bodies (CB1, CB2), and the distributors and exporters (DE1, DE3, DE4). 
It is worth mentioning that due to the large prominence of organic cocoa in STP's economy, a designated agency should exist (e.g., STP Organic Cocoa Board), which would have custody of the policy development and management of cocoa sustainabilityrelated interventions and policies (CB1, CB2, PC1, PC2, PC3, DE2). This would include the improvement of the beans' quality standards, the purchase terms and prices of organic cocoa, and the registration and overseeing of it all. In this respect, the creation of a protected geographical indication (PGI), as Prazeres [9] and Prazeres and Lucas [10] suggested, is viewed by PC3, DE4, and ST5 as a way to protect organic cocoa-specific beans and promote their unique characteristics, which are linked to their geographical origin as well as traditional know-how. A PGI's recognition of organic cocoa can be granted to its specific link to the place where it is made (STP). This recognition enables consumers to trust and distinguish quality products while helping STP producers and their cooperatives better market their products. Additionally, this legal figure (PGI) mentioned by the research center representative (RC1), which is linked to a quality policy, would contribute to an increase in the income of cocoa farmers and the reduction of poverty in rural areas.

\subsection{Perceptions of Sustainability Drivers}

The respondents suggested very diverse factors, which were interrelated as drivers of the sustainability levels of smallholders' organic cocoa. These factors are related to (a) price stability and nondependency on a few buyers (OCPs, C1, C2, ST1, ST4); (b) market access and stability (OCPs, ST1, ST2, CB1); (c) strong farmers' associations and cooperatives with high bargaining power (GI2, NGO1, ST3, C2); (d) containment/diminishing of environmental problems, such as losses of soil fertility and biodiversity (CB1, CB2); (e) training and other initiatives to improve farming practices, production, and productivity (RC1, PC2, ST2, C1); (f) increase in genetic selection and the quality of organic cocoa plants ( $\mathrm{RC} 1, \mathrm{C} 1, \mathrm{C} 2, \mathrm{OCPs}) ;(\mathrm{g})$ diminishing gaps between sustainable standards and practices and cocoa value chain governance; $(\mathrm{h}$ ) changes made in the organic cocoa fermentation, transformation, and commercialization processes (RC1, C1, PC1, PC2, PC3); and (i) other expectations of positive impacts. Thus, there are three major groups of factors driving organic cocoa value chain sustainability, one related to the market, the other connected to the smallholder livelihoods, and the third linked to ecosystems and environmental preservation.

Concerning the market (access, stability, prices, consumer demand, market linkages, and changes), for approximately one-half of the producers (OCPs), the marketing chain is long and ineffective and oriented towards the export market, which remains the benchmark for determining organic cocoa prices. For others, achieving premium pricing is one of the most important drivers of sustainability improvement among cocoa smallholders. This is because these smallholders perceive premium prices as a good reward for their work and invested time and resources.

The premium price of organic cocoa as the main driver of smallholders' engagement in sustainability practices is acceptable and understandable. Premium price will be an extra payment to compensate/incentivize organic cocoa smallholders who ensure sustainable production. Although the price of both conventional and organic cocoa beans is defined by the world market, the direct payment of a premium price for organic cocoa to the farmers, through associations or cooperatives accounts, will be a driver for better adoption and improvement of sustainable practices. The lack of premium prices paid directly to the producer as a reward for his good work towards sustainability is potentially due to the governance of the global cocoa value chain, especially in the further downstream links (CB1, CB2, PC2, ST3). It is concentrated in a few agents, creating asymmetric power relations, which block the distribution and transmission of upstream value to small producers. 
National consumption of chocolate is low and perceived by the OCPs in the focus group to be an expensive tourist product. On the other hand, the international consumer is geographically distant from production, which results in difficult linkages and involvement with the country and the production practices. The reduction of these gaps can allow for an improvement in sustainable practices, such as the organic mode of production and cultural practices in land use and other resources, as well as organic cocoa value chain governance (ST2, CB1, CB2, NGO1). According to the vision presented in these interviews, international consumer pressure can play a critical role in the improvement of sustainability and the adoption of organic certification on a broad scale. This is due to the influence of an increase in consumer awareness, demand for sustainability, and increase in the purchase of sustainable products belonging to smallholder productions.

Concerning smallholder livelihoods, the soil is one of the most important resources. Therefore, there was a common agreement among the participants across the 10 focus groups that a good soil can support cocoa sustainability growth and increased crop yield, which translates into increased household income and better living standards (OCPs). The majority of OCPs also believe that the sustainability of their farms is dependent on the provision of subsidies and aids. This is because cash availability is the main challenge they face, and it is invariably required to adopt enhanced sustainability practices. It should be noted that one of the most prominent drivers of sustainable production mentioned by the OCPs and cooperatives $(\mathrm{C} 1, \mathrm{C} 2)$ concerns access to extension services/capacity building and agricultural resources. Both are done by sociotechnicians and cooperatives and are particularly relevant to changing and/or adopting new practices towards sustainability, those that can mitigate climate change risks and support soil fertility. This is particularly important to most OCPs who have little training and extension to support sustainable production practices and knowledge on how to tackle cocoa plant diseases and pest infestation (RC1, C1, CB2, PC2). The high cost of organic fertilizers, even though there is no upfront payment, places large financial burden on smallholders (OCPs, NGO1, PC1, C1, ST2, ST5) and further erodes their overall income (C1, C2, GI2). Fortunately, they have the cooperatives' collateral to purchase inputs on credit or access loans (C1, C2, ST4). By joining the cooperative, smallholders usually benefit from better access to organic cocoa inputs in many ways. Cooperatives and their farmers' associations can serve as collateral for accessing inputs on credit and service this debt after harvest (C1, C2, ST1, ST2, ST3, ST4, ST5). Some governmental institutions and related agencies and programs purchase inputs and distribute them to cocoa farmers according to their farm requirement (GI2, OCPs). A few smallholders directly use their own money to buy agricultural inputs (OCPs), and others access loans or financial programs from COMPRAN (a project to support marketing, agricultural productivity, and nutrition) or other subsidized credit bank programs to buy input.

COMPRAN, started in June 2020, is a project cofinanced by the government of STP and IFAD. Despite the existence of different pathways to organic cocoa producers' empowerment, the facilitation of empowerment processes should be mentioned as a smallholder's great need (C1, PC3). Simultaneously, perceptions reveal that there are multiple avenues to empower organic smallholders in financial, social, and gender terms (CB1, ST5, NGO1, PC2, DE3). Some organic smallholders mentioned that they were trained on issues pertaining to gender and child labor (OCPs).

Finally, the study regarded a group of drivers concerned with environmental and ecosystem preservation. Environmental sustainability is viewed as a major factor in connection to organic cocoa. This production mode is considered an important starting point to improving the organic cocoa value chain's sustainability (C1, C2, G1, PC2, PC3, RC1, DE2, ST1, ST5). However, some participants in the study defend the need to reorient organic cocoa farmers' perceptions to improve the visibility of the overall benefits of sustainable organic cocoa production (CB2). More cooperation between the public and private sectors is mentioned by some participants (CB2, RC1, NGO1) as a way to get better environmental 
preservation, avoid deforestation, and integrate more trees in the organic cocoa ecosystem (CB1, ST2). A representative of a government institution (GI2) stated that one crucial pathway for the achievement of environmental sustainability is the integration of the young generation in different levels of the organic cocoa value chain (from production to processing). The justification is that young people are more responsive to the future of the planet. For another representative (GI4), this is also a way to achieve the social dimension of sustainability. However:

"Only producers well trained and well paid can produce very good sustainable organic cocoa."

(RC2, CB2, DE1-Open qualitative interview)

\subsection{Perceptions of the Sustainability Impacts and Barriers}

The perceived impacts underlying the sustainability impacts as reflected in the interviews and focus group are positive and negative. The positive impacts are mostly perceived as being related to the reduced environmental pollution and preservation of water sources (ST2, CB1, CB2, GI1, GI3, RC1), the possibility of having productivity gains due to greater capacity building access (GI2, C2), the decrease in deforestation and biodiversity loss (RC1, NGO1), the income gains (OPC, C1, ST3), and the improvement in farmer well-being and health, diminishing the associated burdens (PC2, CB1, ST1, C1).

Concerning the negative impacts, the individuals interviewed and the focus group suggested several financial, operational, marketing, capacity (organic cocoa farmers' low education and lack of technical know-how), and institutional issues as the main barriers of the chain. Low education level often constrains effective smallholder training, which seeks to implement better innovative practices (GI1, ST4, DE2). The financial barrier is the most mentioned barrier because cost increase is perceived to be linked to sustainability's improvement (OCPs, C1, C2, GI2, PC3). Both smallholders and large private companies perceive the high cost of sustainability improvement in the organic cocoa value chain (PC1, PC2, PC3, C1, ST4, ST5, DE3, DE4). It is considered closely related to the changes that should be made in some operations to internalize the innovative sustainability processes, requiring specialized staff recruitment and significant financial commitments that are beyond the financial capacity of private companies and cooperatives (ST2, ST4, C1, C2, PC3). Even in the cooperatives, where organic cocoa farmers are organizing into groups as a means of reducing costs, these are still perceived to be prohibitive (C1, C2, ST1, ST3, GI3, GI4). For some OCPs and PC (1 and 2), ensuring the sustainability of the cocoa value chain requires support and consistency in governmental policies and banking support programs, as well an increase in the farmers' bargaining position by strengthening farmer cooperatives and associations and support from them.

The operational barriers to sustainability improvement mentioned tend to be concentrated around heavy bureaucracy, lack of organic cocoa value chain governance, lack of farmer knowledge, and corruption (PC2, ST3, NGO1, DE1). In more detail, the cooperatives pointed out the extensive documentation of organic cocoa production principles, guidelines, and criteria (C1, C2, ST3, ST5). The bureaucracy when dealing with national authorities is sustained by the certification bodies (CB1, CB2). Finally, the proliferation of different organic certification schemes (with different processes, guidelines, criteria, and principles) tends to confuse many smallholders in their implementation (C1, ST3, PC3).

An organic cocoa production mode and its certification require extensive recordkeeping (e.g., cocoa farm activities, auditing), which is supported by the farmer cooperatives. To do that, there is a need for a specialized highly technical staff, and the existing staff often lacks capacity for this, and the same will occur in the future sustainability management (C1, C2, ST1, ST2). 
Marketing barriers include lack of payment of premium prices by consumers and unknown market demand for sustainable cocoa products. In this case, some organic cocoa products can end up being sold as conventional products in global markets, despite their quality and the added effort/cost of the organic production mode (PC1, PC3, ST4).

Finally, diverse policy factor constraints are perceived to be barriers to sustainability improvement. These encompass inconsistent government policies, lack of clarity over land tenure, and mostly importantly, lack of a comprehensive national policy for the cocoa sector. Despite the fact that cocoa organic production is being led by the cooperatives and supported by government institutions, agencies, and programs, government policies and measures are not consistent throughout the years and are often affected by the existing government of the day (PC2, PC3, CB1, CB2). This poses barriers to the advanced planning of organic cocoa activities and the effective implementation of sustainability requirements related to pyrotechnical treatments (PC3, DE3). Such inconsistencies also affect the cooperatives and other stakeholders (producers' associations and sociotechnicians) who are tasked to support smallholders (ST1, ST3). Apart from the barriers posed by prevailing land tenure rules, which always belong to the state, tree tenure can also be controversial (OCPs, ST1). Assuming that organic cocoa farmers are encouraged to incorporate shade trees in their farms, all the autocratic processes related to this and to the further exploitation of planted trees disincentivize the integration of these trees (PC1, PC3, ST5).

Finally, the major barrier concerns the lack of a comprehensive national policy for the promotion and sustainable development of the organic cocoa value chain (ST3, PC4, NOG1, RC1, DE4). This partially invalidates the widespread improvement of a sustainability agenda (CB1, CB2). Strengthening cocoa farmer cooperatives to collaborate more deeply with industry and research institutions and improving the implementation of the cocoa organic farming system to fulfill the international community's demand for healthy organic products are recommended by the certification bodies' representatives (CB1, CB2) and traders (DE1, DE3).

\section{Discussion}

The findings of this work expose disparities in the perceptions obtained from the stakeholders contacted according to their experiences within the scope of the role they play in their respective link of the value chain. However, the sustainability pathway implies collaborative work between multiple stakeholders involved in a holistic perspective, aiming for the development of an inclusive strategy that can create benefit for all the players of the organic cocoa value chain [33].

As this exploratory study has shown, numerous often interrelated factors can be perceived as influencers of the sustainability of the organic cocoa value chain. This encompasses stakeholders from different levels, including the governance of the organic cocoa value chain. There was a common agreement among the stakeholders engaged in the study that organic cocoa is set to expand in the future due to not only increasing demand for chocolate but also STP's government project and plan for its increase (e.g., [34]). This perspective is also echoed in recent reports [35] and the academic literature [36-40], although the potential of organic cocoa as a solution to agricultural sustainability challenges is unclear [39].

The discussions centered around sustainability perceptions and how to achieve growth in their three dimensions with a range of contributions emerging from the discussions and interviews. Vogel et al. [13] highlighted that an analysis of transition pathways without an assessment of the overall stakeholder contribution to sustainability outcomes provides an incomplete picture of the underlying challenges that need to be addressed. Additionally, for Adiyah et al. [40], the adoption of good sustainability practices is dependent on the economic status of cocoa farmers. The study also highlights the relationship between farmers' training and changes in their adopted practices and how these practices can mitigate climate change; support soil fertility [40], productivity, and profitability; and avoid land degradation [39]. Farmers' training provides better knowledge on pest control [36] and 
other sustainability issues, such as greenhouse gases, profitability, and gender equity [39] or deforestation $[1,41]$.

Most stakeholders also identify market-related factors (premium prices, consumer demand, market access, and social difference within the cocoa value chain) as, simultaneously, the main constraints and drivers among smallholders, their cooperatives, and private companies. These results are in line with previous research [36,42,43], which showed that cocoa farmers in Indonesia, Cameroon, and Peru perceive the marketing chain to be long and ineffective and oriented towards the international market. These factors determine domestic organic cocoa prices and expressed concerns about low pricing, price volatility, difficulty in accessing the market, small-scale production, low productivity, and lack of partnerships.

The sustainability improvement in the organic cocoa value chain is perceived to be associated with positive economic, social, and environmental impacts, such as income generation, farm productivity gains, and reduced deforestation and pollution. This is in line with a study by Ingram et al. [3] in West Africa. Nevertheless, the organic cocoa value chain is perceived to be facing multiple financial, institutional, marketing, capacity, and operational barriers to achieve this sustainability improvement. Moreover, equity in governance and power dynamics within the organic cocoa value chain would be necessary to ensure the widespread improvement of the sustainability dimensions, which would be translated into positive sustainability outcomes. Additionally, a study by Lalwani et al. [44] highlighted the importance of reducing social differences and asymmetries of power within the cocoa value chain.

The stakeholders' suggestion of strengthening the cooperatives' relationships with the industry and research institutions to improve the organic cocoa value chain's sustainability and fulfill international demand for healthy organic products is in line with other studies [36]. However, ensuring the sustainability of the cocoa value chain requires support and consistency in government policies and banking support programs as well as better performance of smallholder cocoa farmers. Thus, it is necessary to increase the bargaining position of organic cocoa farmers by strengthening their cooperatives and associations and communicating cocoa benefits to society [45].

In all dimensions of organic cocoa production, the measures that reduce land degradation, improve market access and profitability, enhance social integration through gender equity and accountability are the main driving forces to ensure the sustainability performance of a farming system. This commitment to sustainability matters, and in STP's context, it should be deeply encouraged to improve sustainability and ensure balance in all its dimensions, conforming with a study by Bandanaa et al. [39]. Despite the efforts made by the CECAB and CECAC11 cooperatives, their associations, extension divisions, government departments, and agencies of agriculture, more actions should be encouraged to improve and balance all the sustainability dimensions.

Several sustainability challenges related to the organic cocoa value chain have been identified both in the literature $[43,46]$ and in this study. These mainly relate to the economic dimension of sustainability (governance and powers and interactions of various stakeholders along the value chain), but also, and less, to the environmental [47] and social [44] dimensions.

Relevant emerging topics arose throughout the study, which were repeated by various respondents during the interviews, focus group discussion, and field observation. Such topics include identifying the livelihood strategies of small cocoa producers; determining market diversification; understanding how organic cocoa chain governance mechanisms, structures, and policies improve sustainability and add value to farmers; and analyzing the value added as well as the relationships between the value components and sustainability. This means producing alternatives to organic cocoa beans for exportation and diversification at the production level in order to expand crop types, adding value and further sources of income to smallholder farmers. This is one crucial aspect for the economic and social dimensions of sustainability in the future. The sustain- 
able development of a national organic cocoa processing industry and market was also mentioned and perceived to be promising. This is in progress in one of the cooperatives, which aims to transform organic cocoa beans into diversified products within internal boundaries, retaining the added value in STP. The need to attract and integrate younger generations to the organic cocoa value chain is another emergent topic. This can be done through education, land tenure, financial access, and further interventions, incentives, and initiatives.

\section{Conclusions}

This study contributed to the sustainability transition research by eliciting the perspectives of the main stakeholders engaged in the organic cocoa value chain in STP to explore and evaluate future directions and challenges towards a more sustainable value chain.

Mapping the stakeholders' perceptions is a step towards going further in the organic cocoa value chain research, particularly in issues such as livelihood strategies of organic cocoa farming households, prevention or mitigation of the perceived negative impacts, and governance improvement. All these were pointed out by the participants in the study, who were involved directly or indirectly in the organic cocoa value chain. Additionally, in the development of transition pathways to improve sustainability in STP's organic cocoa value chain, it is useful to emphasize the role and contribution of different actors to define and develop those transition pathways. The assessment of stakeholders perceptions strengthens the analysis by providing insights into the drivers and barriers to the transition towards sustainability and how policymakers, cooperative managers, and other actors can promote and support a deeper and more inclusive sustainability transition process.

The stakeholders have common and different perceptions and agendas on the drivers, impacts, challenges, and pathways to sustainability improvement. There was a broad consensus among all the participants on the most likely pathway, that is, not a complete process shift but rather a continuance of the dominant organic mode of cocoa production with a gradual shift towards a higher sustainability level, through improvements in all value chain steps and processes. Most of the participants also identified market-related factors (premium prices, consumer demand, and market access) as, simultaneously, the main constraints and drivers among smallholders, their cooperatives, and private companies.

The findings are supported by the literature, which highlights the power of stakeholders as change agents and as individuals who are resilient to most sustainability challenges in the chain. By reflecting the diversity of stakeholders' foci, despite being exploratory, the results are useful in order to find a path towards more sustainability in the organic cocoa value chain, as a broader sustainability perspective is needed. There is a lack of a holistic approach to tackle all of the sustainability dimensions-economic, social, and environmental - in the cocoa value chain [48]. We therefore conclude that there is still a long way to go in order to fully expand on the existing sustainability levels of the organic cocoa value chain.

Author Contributions: Conceptualization, I.P.; methodology, I.P.; validation, I.P. and M.R.L.; formal analysis, I.P., M.R.L., and A.M.-C.; investigation, I.P.; resources, I.P.; data curation, I.P.; writingoriginal draft preparation, I.P.; writing-review and editing, I.P., M.R.L., and A.M.-C.; visualization, I.P.; supervision, M.R.L. and A.M.-C.; project administration, I.P., M.R.L., and A.M.-C.; funding acquisition, I.P., M.R.L., and A.M.-C. All authors have read and agreed to the published version of the manuscript.

Funding: This research is supported by national funds through the FCT (Portuguese Foundation for Science and Technology) under the projects UIDB/04011/2020 and UIDB/04007/2020.

Data Availability Statement: Not applicable.

Conflicts of Interest: The authors declare no conflict of interest. 


\section{Nomenclature}

$\begin{array}{ll}\text { ADAPPA } & \text { Action for Agricultural Development and Environmental Protection } \\ \text { ADIL } & \text { Local Initiatives Development Action } \\ \text { C } & \text { Cooperatives } \\ \text { CB } & \text { Certification bodies } \\ \text { CECAB } & \text { Cooperative for the Production and Export of Organic Cocoa } \\ \text { CECAC11 } & \text { Cooperative for the Production and Export of Cocoa } \\ \text { CIAT } & \text { Centre for Agronomic and Technological Research } \\ \text { DE } & \text { Distributors and exporters } \\ \text { FENAPA } & \text { National Federation of Small Farmers } \\ \text { GI } & \text { Governmental institutions } \\ \text { IFAD } & \text { International Fund for Agricultural Development } \\ \text { NGO } & \text { Nongovernmental organization } \\ \text { OC } & \text { Organic cocoa } \\ \text { OCPs } & \text { Organic cocoa producers } \\ \text { PAPAC } & \text { Smallholder Commercial Agriculture Project } \\ \text { PC } & \text { Private companies } \\ \text { RC } & \text { Research center } \\ \text { ST } & \text { Sociotechnicians } \\ \text { STP } & \text { São Tomé and Príncipe }\end{array}$

\section{References}

1. Recanati, F.; Marveggio, D.; Dotelli, G. From beans to bar: A life cycle assessment towards sustainable chocolate supply chain. Sci. Total Environ. 2017, 613-614, 1013-1023. [CrossRef]

2. Wessel, M.; Quist-Wessel, F.F. Cocoa production in West Africa, a review and analysis of recent developments. NJAS Wagening. J. Life Sci. 2015, 74. [CrossRef]

3. Ingram, V.; van Rijn, F.; Waarts, Y.; Gilhuis, H. The Impacts of Cocoa Sustainability Initiatives in West Africa. Sustainability 2018, 10, 4249. [CrossRef]

4. Matissek, R.; Reinecke, J.; Von Hagen, O.; Manning, S. Sustainability in the Cocoa Sector-Review, Challenges and Approaches; Moderne Ernaehrung Heute, Official Journal of the Food Chemistry Institute of the Association of the German Confectionery Industry, Ernährung: Cologne, Germany, 2012; pp. 1-27.

5. Blare, T.; Useche, P. Competing objectives of smallholder producers in developing countries: Examining cacao production in Northern Ecuador. Environ. Econ. 2013, 4, 71-79.

6. Díaz-Montenegro, J. Livelihood Strategies of Cacao Producers in Ecuador: Effects of National Policies to Support Cacao Farmers and Specialty Cacao Landraces. Ph.D. Thesis, Institut de Sostenibilitat, Universitat Politècnica de Catalunya, Barcelona, Spain, 2019.

7. Voora, V.; Bermúdez, S.; Larrea, C. Global Market Report: Cocoa; Sustainable Commodities Marketplace Series 2019; IISD-The International Institute for Sustainable Development: Manitoba, Canada, 2019; Available online: https://www.iisd.org/system/ files/publications / ssi-global-market-report-cocoa.pdf (accessed on 23 September 2021).

8. Prazeres, I.; Lucas, M.R.; Marta-Costa, A. Cocoa Markets and Value Chains: Dynamics and Challenges for Sao Tome and Principe Organic Smallholders. Int. J. Innov. Econ. Dev. 2021, 7, 64-77. [CrossRef]

9. Prazeres, I.C. Estratégia de Marketing e Criação de Valor do Cacau Biológico de São Tomé e Príncipe no Mercado Internacional. Master's Thesis, Especialização em Marketing, Universidade de Évora, Évora, Portugal, 2018.

10. Prazeres, I.C.; Lucas, M.R. Repensar a cadeia de valor do cacau biológico de São Tomé e Príncipe. Rev. Ciências Agrárias 2020, 43 , 48-60. [CrossRef]

11. ANEME-Associação Nacional das Empresas Metalúrgicas e Eletromecânicas. Estudo de Levantamento e Caracterização das Empresas Industriais de São Tomé e Príncipe. Estudo São Tomé e Príncipe; ANEME: Lisbon, Portugal, 2018; pp. 1-252.

12. Levai, L.D.; Meriki, H.D.; Adiobo, A.; Awa-Mengi, S.; Akoachere, J.; Titanji, V. Postharvest practices and farmers' perception of cocoa bean quality in Cameroon. Agric. Food Secur. 2015, 4, 1-8. [CrossRef]

13. Vogel, C.; Mathé, S.; Geitzenauer, M.; Ndah, H.T.; Sieber, S.; Bonatti, M.; Lana, M. Stakeholders' perceptions on sustainability transition pathways of the cocoa value chain towards improved livelihood of small-scale farming households in Cameroon. Int. J. Agric. Sustain. 2020, 18, 55-69. [CrossRef]

14. Dolisca, F.; McDaniel, J.M.; Shannon, D.; Jolly, C.M. A multilevel analysis of the determinants of forest conservation behavior among farmers in Haiti. Soc. Nat. Resour. 2009, 22, 433-447. [CrossRef]

15. Greiner, R.; Gregg, D. Farmers' intrinsic motivations, barriers to the adoption of conservation practices and effectiveness of policy instruments: Empirical evidence from northern Australia. Land Use Policy 2011, 28, 257-265. [CrossRef] 
16. Liu, T.; Bruins, R.J.F.; Heberling, M.T. Factors Influencing Farmers' Adoption of Best Management Practices: A Review and Synthesis. Sustainability 2018, 10, 432. [CrossRef] [PubMed]

17. Tosakana, N.; van Tassell, L.; Wulfhorst, J.; Boll, J.; Mahler, R.; Brooks, E.; Kane, S. Determinants of the adoption of conservation practices by farmers in the Northwest Wheat and Range Region. J. Soil Water Conserv. 2010, 65, 404-412. [CrossRef]

18. Ansah, E.O.; Kaplowitz, M.D.; Lupi, F.; Kerr, J. Smallholder participation and procedural compliance with sustainable cocoa certification programs. Agroecol. Sustain. Food Syst. 2020, 44, 54-87. [CrossRef]

19. Dompreh, E.B.; Asare, R.; Gasparatos, A. Stakeholder perceptions about the drivers, impacts and barriers of certification in the Ghanaian cocoa and oil palm sectors. Sustain. Sci. 2021, 16, 2101-2122. [CrossRef]

20. Winter, S.C.; May, P.J. Motivation for Compliance with Environmental Regulations. J. Policy Anal. Manag. 2001, 20, 675-698. [CrossRef]

21. Hindriks, F.; Guala, F. Institutions, rules, and equilibria: A unified theory. J. Inst. Econ. 2015, 11, 459-480. [CrossRef]

22. Lambin, E.F.; Thorlakson, T. Sustainability standards: Interactions between private actors, civil society, and governments. Annu. Rev. Environ. Resour. 2018, 43, 369-393. [CrossRef]

23. Lang, D.J.; Wiek, A.; Bergmann, M.; Stauffacher, M.; Martens, P.; Moll, P.; Swilling, M.; Thomas, C.J. Transdisciplinary research in sustainability science: Practice, principles, and challenges. Sustain. Sci. 2012, 7, 25-43. [CrossRef]

24. Ahmed, A.; Campion, B.; Gasparatos, A. Towards a classification of the drivers of jatropha collapse in Ghana elicited from the perceptions of multiple stakeholders. Sustain. Sci. 2019, 14, 315-339. [CrossRef]

25. Karanja, A.; Mburu, F.; Gasparatos, A. A multi-stakeholder perception analysis of the adoption, impacts and priority areas in the Kenyan clean cooking sector. Sustain. Sci. 2020, 15, 333-351. [CrossRef]

26. FAO. Developing Sustainable Food Value Chains_Guiding Principles; FAO: Rome, Italy, 2014; pp. 1-89.

27. United Nations. Transforming Our World: The 2030 Agenda for Sustainable Development; A/RES/70/1; United Nations: New York, NY, USA, 2015; pp. 1-35.

28. ICCO. Sustainable Cocoa Economy: Comprehensive and Participatory Approach; ICCO: Kuala Lumpur, Malaysia, 2007; pp. 1-10.

29. The European Parliament and The European Council. Directive (EU) 2016/680 of the European Parliament and of the Council of 27 April 2016, on the Protection of Natural Persons with Regard to the Processing of Personal. Off. J. Eur. Union 2016, 119, 89-131.

30. Terry, G.; Hayfield, N.; Clarke, V.; Braun, V. Thematic Analysis. In The SAGE Handbook of Qualitative Research in Psychology, 2nd ed.; Willig, C., Rogers, W.S., Eds.; SAGE Publications: London, UK, 2017; pp. 17-37.

31. Ginting, W.A.; Ambarawati, I.G.A.A.; Dewi, I.A.L. The role of UTZ certified program on increasing production and income of cocoa farmers in Jembrana Regency, Bali Province. Agrisocionomics 2019, 3, 68-76. [CrossRef]

32. Jones, S.; Gibbon, P. Developing agricultural markets in Sub-Saharan Africa: Organic cocoa in rural Uganda. J. Dev. Stud. 2011, 47, 1595-1618. [CrossRef]

33. Doherty, B.; Kittipanya-Ngam, P. The role of social enterprise hybrid business models in inclusive value chain development Sustainability 2021, 13, 499. [CrossRef]

34. Sarmento, F. São Tomé e Príncipe na Construção de um Pacto Nacional para a Agroecologia, 1st ed.; Associação para a Cooperação e Desenvolvimento (ACTUAR), Ação para o Desenvolvimento Agropecuário e a Proteção do Ambiente (ADAPPA), Instituto Marquês de Vlae Flor (IMVF): Lisboa, Portugal, 2021; pp. 1-45.

35. MRW-Market Reports World. Organic Cocoa Industry Size, Share 2021. Global Future Growth, Regional Trend, Leading Players Updates, Industry Demand, Current and Future Plans by Forecast to 2022. Press Release Distributed by The Express Wire. 2021 Available online: https:/ / www.marketreportsworld.com/enquiry/request-sample/10899698 (accessed on 23 September 2021).

36. Leksono, A.S.; Mustafa, I.; Gama, Z.P.; Afandhi, A.; Zairina, A. Organic cocoa farming in Indonesia: Constraints and development strategies. Org. Agric. 2021, 11, 445-455. [CrossRef]

37. Ouattara, L.Y.; Kouassi, E.K.A.; Soro, D.; Soro, Y.; Yao, K.B.; Adouby, K.; Drogui, A.P.; Tyagi, D.R.; Aina, P.M. Cocoa pod husks as potential sources of renewable high-value-added products: A review of current valorizations and future prospects. BioResources 2021, 16, 1988-2020. [CrossRef]

38. Seufert, V.; Ramankutty, N. Many shades of gray the context-dependent performance of organic agriculture. Sci. Adv. 2017, 3, e1602638. [CrossRef]

39. Bandanaa, J.; Asante, I.K.; Egyir, I.S.; Schader, C.; Annang, T.Y.; Blockeel, J.; Kadzere, I.; Heidenreich, A. Sustainability performance of organic and conventional cocoa farming systems in Atwima Mponua District of Ghana. Environ. Sustain. Indic. 2021, 11, 100121. [CrossRef]

40. Adiyah, F.; Fuchs, M.; Michéli, E.; Dawoe, E.; Kovács, E. Cocoa farmers' perceptions of soil organic carbon effects on fertility, management and climate change in the Ashanti region of Ghana. Afr. J. Agric. Res. 2021, 17, 714-725. [CrossRef]

41. Orozco-Aguilar, L.; López-Sampson, A.; Leandro-Muñoz, M.E.; Robiglio, V.; Reyes, M.; Bordeaux, M.; Sepúlveda, N.; Somarriba, E. Elucidating pathways and discourses linking cocoa cultivation to deforestation, reforestation, and tree cover change in Nicaragua and Peru. Front. Sustain. Food Syst. 2021, 5, 635779. [CrossRef]

42. Mithöfer, D.; Roshetko, J.M.; Donovan, J.A.; Nathalie, E.; Robiglio, V.; Wau, D.; Sonwa, D.; Blare, T. Unpacking 'sustainable' cocoa: Do sustainability standards, development projects and policies address producer concerns in Indonesia, Cameroon and Peru? Int. J. Biodivers. Sci. Ecosyst. Serv. Manag. 2017, 13, 444-469. [CrossRef]

43. Teye, J.K.; Nikoi, E. The Political Economy of the Cocoa Value Chain in Ghana; APRA Working Paper 53; Future Agricultures Consortium: Brighton, UK, 2021; pp. 1-42. [CrossRef] 
44. Lalwani, S.K.; Nunes, B.; Chicksand, D.; Boojihawon, D.K. Benchmarking self-declared social sustainability initiatives in cocoa sourcing. Benchmarking 2018, 25, 3986-4008. [CrossRef]

45. Arfah, S.Y.C. Strategy for cocoa agribusiness development in Central Sulawesi. J. Agroland 2019, 26, 179-188.

46. Grabs, J.; Carodenuto, S.L. Traders as sustainability governance actors in global food supply chains: A research agenda. Bus. Strategy Environ. 2021, 30, 1314-1332. [CrossRef]

47. Castro-Nunez, A.; Charry, A.; Castro-Llanos, F.; Sylvester, J.; Bax, V. Reducing deforestation through value chain interventions in countries emerging from conflict: The case of the Colombian cocoa sector. Appl. Geogr. 2020, 123, 102280. [CrossRef]

48. Prazeres, I.; Lucas, M.R.; Marta-Costa, A. Sustainable Cocoa Value Chain-A review and Critical Analysis of 'Triple Bottom Line' Scenarios. In Impacts of Climate Change and Economic and Health Crises on the Agriculture and Food Sectors; Martinho, V., Ed.; IGI Global Publisher: Hershey, PA, USA. 